\title{
THE QUEST TO RECOGNISE THE HISTORICAL AND LEGAL PREVALENCE OF THE TRANSGENDER IN INDIA
}

\author{
Abhishek Raj \\ Ranchi University, Jharkhand, India \\ DOI: 10.46609/IJSSER.2020.v05i06.005 URL: https://doi.org/10.46609/IJSSER.2020.v05i06.005
}

\begin{abstract}
Gender as a concept is not limited to men and women only. It is a much wider concept, a spectrum. When we talk about gender, the inclusion of transgender cannot be denied. The paper starts with an introduction to get acquainted with the word 'transgender' in its terminological sense, to avoid any confusion. It has become a major concern for the world to realize that people belonging to transgender community are also human beings. They are not any threat to humanity and have been in existence since time immemorial. For this purpose the paper primarily focuses on evidences from cultural and religious history where they were given due consideration and recognition. Evidences from ancient cultural and religious scriptures like that of Mahabharata, Naradasmriti, Sushruta Samhita, Charaka Samhita and most importantly the Kamasutra have been discussed in the paper. From these references it is understood that transgender community possesses some cultural and religious legacy. The paper also sheds light on Bahuchara Mata (Goddess of fertility) worshipped by members of transgender community (mainly hijras) as their patroness. An attempt has also been made to analyze the struggle faced by the transgender community to gain legal recognition in India. With the intention of exploring the legal status, landmark judgements and laws favouring the transgender community have been used as reference. The paper also attempts to give a vivid description of "The Transgender Persons (Protection of Rights) Bill, 2016" which is yet to become a law.
\end{abstract}

Keywords: Gender, Rights, Law, Transgender

\section{AN INTRODUCTION TO TRANSGENDER}

It's important to examine the concept of 'gender' before discussing the term 'transgender'. We commence by differentiating sex from gender. Sex refers to biological and physical characteristics that are linked with being labelled as male or female. Sex is labelled at birth, 


\section{International Journal of Social Science and Economic Research}

Volume: 05, Issue: 06 "June 2020"

usually on the basis of genitalia. Gender is the range of characteristics pertaining to, and differentiating between, masculinity and femininity and others described as 'third-gender'. World Health Organization states, "Sex refers to the biological and physiological characteristics that define men and women" and "gender refers to the socially constructed roles, behaviours, activities, and attributes that a given society considers appropriates for men and women".

The term 'transgender' was coined by John F. Oliven of Columbia University in his work "Sexual Hygiene and Pathology" (1965). The word 'transgender' is an umbrella term for people whose gender identity is different from the sex assigned to them at birth. We need to understand that gender is different from sexual orientation and this leads to the fact that transgender people could be of any sexuality. Leslie Feinberg (1949-2014) was an American transgender activist. Her pamphlet "Transgender Liberation: A movement whose time has come", circulated in 1992, identified transgender as term to consolidate all forms of gender non-conformity; in this way transgender has become synonymous with queer. ${ }^{1}$ Some transgender people identify as male or female, and some identify as gender queer, non-binary, or somewhere outside the spectrum of our understanding of gender. Thus, it can be said that the transgender community is incredibly diverse.

\section{The Mahabharata- Tale of Shikhandi, Aravan and Krishna}

There are many versions of Mahabharata which mention about Shikhandi/Shikhandini. Shikhandi is a significant character in Mahabharata. When we talk about Shikhandi's gender then in few versions, Shikhandi is male but born-female. When Shikhandini changes his sex he becomes Shikhandi but is a eunuch. ${ }^{2}$ In a previous lifetime Shikhandi had been born as a woman named Amba. Few versions mention that Amba is simply reborn as a male Shikhandi, sometimes whole and sometimes eunuch. Few versions narrate that Shikhandi is a male but transgender, due to Shiva's boon that Amba will remember all the details of her past life. ${ }^{3}$

Another great example from Mahabharata is that of Aravan and Krishna. Aravan (son of Pandava Prince Arjuna) is a minor character in the Mahabharata. According to Mahabharata, Aravan had agreed to sacrifice himself to secure Dharma but on one condition. He wanted a widow to weep for him when he died the next day. No woman was willing to marry him just for one night and get widowed the following day. Pandavas had to find a means of fulfilling the last wishes of a sacrificial man. Consequently, Krishna transformed himself into a woman (Mohini)

\footnotetext{
${ }^{1}$ Stryker, Susan. "Transgender History, Homonormativity, and Disciplinarity." Radical History Review, Dec 2008, vol. 2008, no. 100, pp. 145-157, Duke University Press. read.dukeupress.edu/radical-history-review/articleabstract/2008/100/145/22107/Transgender-History-Homonormativity-and.

${ }^{2}$ Cornelia, Sorabji, Shikhandi: The Maiden-knight and Other Stories. Blackie and Son, 1916.

${ }^{3}$ Pattanaik, Devdutt. Shikhandi and other tales they don't tell you. Zubaan and Penguin India, 2014.
} 
International Journal of Social Science and Economic Research

ISSN: $2455-8834$

Volume: 05, Issue: 06 "June 2020"

and married Aravan and wept the next day when Aravan martyred himself. The myth of Aravan is greatly revered by the transgender community. Aravan is a patron God of well-known transgender communities called Thirunangai (also Aravani in Tamil, and Hijra throughout South Asia). ${ }^{4}$

Tamil Nadu's Koovagam Village is famous for the unique 18-day long festival of transgender in the Tamil month of Chitirai (April/May). Thousands of transgender from across the country congregate at Koothandavar Temple dedicated to Aravan and take part in the Koovagam Festival by re-enacting the marriage of Aravan and Mohini.

\section{The Ramayana- Origin of Badhai}

The Ramayana gives a brief account of the existence of transgender. Scholars like A.K. Ramanujan and Camille Bulcke opine that, as many as 300 versions of Ramayana are known to exist. According to some versions, when Lord Rama was leaving Ayodhya for his exile, a crowd of his subjects had followed him into the forest. Noticing this crowd of devotees, Rama requested them not to mourn for him and told that all the "men and women" of the crowd should return to their places in Ayodhya. When Rama returned to Ayodhya after 14 years, he found the hijras, being "neither men nor women", had not moved from the place where he had addressed them. Impressed with their devotion, Rama granted hijras the boon to confer blessings on people during auspicious occasion like childbirth and weddings. This boon is the origin of 'Badhai' in which hijras sing, dance and give blessings. ${ }^{5}$

\section{Naradasmriti- On Homosexuality}

Naradasmriti is one of the ancient Hindu texts that mentions about homosexuality. In Naradasmriti, sage Narada identifies 14 different types of men who are impotent with women. The list includes transgender people (Sandha), intersex people (nisarga), and different types of homosexual men (mukhebhaga, kumbhika and asekya). All three types are declared unalterable and are barred from marrying women. Most importantly, the text does not condemn the 'thirdsex' as unnatural.

\section{Sushruta Samhita- Male, Female and the Third-Sex}

\footnotetext{
${ }^{4}$ Somasundaram, O. "Transgenderism: Facts and Fictions". Indian Journal of Psychiatry, Jan-Mar 2009, 51(1), pp. 73-75. Miscellany, www.indianjpsychiatry.org/temp/IndianJPsychiatry51173-2388112_063801.pdf.

5 Narain, Siddharth. "In a Twilight World". Frontline. Vol. 20, no. 21, Oct 11-24. 2003. frontline.thehindu.com/static/html/fl2021/stories/20031024002509800.htm.
} 
Sushruta Samhita is an ancient Sanskrit text on medicine and surgery (dating back to at least 600 B.C.). It is one of the most important such treatises on this subject to survive from the ancient world. According to Sushruta Samhita, the third sex or gender includes people who conventionally been called homosexuals, bisexuals, transgender people and intersex people (LGBTI). The text mentions two types of homosexual men (kumbhika and asekya) as well as transgender people (Sandha- men with the qualities, behaviour and speech of women). It also states that men who behave like women, or women who behave like men, are determined as such at the time of their conception in the womb (SS.3.2.42-43). ${ }^{6}$ It also mentions the possibility of two women uniting and becoming pregnant as a result of the mingling of their sexual fluids. It states that the child born of such a union will be 'boneless'. The text asserts the fact that all three natures- male, female and the third-sex are determined at the time of conception.

\section{Charaka Samhita- Biological basis for Homosexuality}

Charaka Samhita is a Sanskrit text on Ayurveda (Indian traditional medicine). ${ }^{7}$ It is one of the foundational texts of this field that have survived from ancient India. ${ }^{8}$ The text lists eight types of men who are unable to copulate with women.

- Dviretas- born with both male and female seed

- Pavanendriya- unable to discharge semen

- Samskaravahi- aroused according to previous life impressions

- Narashandha- manhood is completely destroyed

- Narishandha- womanhood is completely destroyed

- Vakri- deformed reproductive organ

- Irshyabhirati- aroused only by seeing others on the act of sexual union

- Vatika- born without testicles

The text asserts that these variations are produced by unchangeable factors such as previous life impressions, parental conditions and certain conditions within the womb. It is thus one of the earliest claims in the world of a biological basis for homosexuality.

\section{Kamasutra- Recognizing the Third-Sex}

\footnotetext{
6 Wilhelm, Amara Das. Tritya-Prakriti: People of the Third Sex: Understanding Homosexuality, Transgender Identity and Intersex Conditions through Hinduism. Xlibris, 2003, pp. 267, 334.

${ }^{7}$ Meulenbeld, Gerrit Jan. A History of Indian Medical Literature, vol. 1A, E. Forsten, 1999, pp.7-180.

${ }^{8}$ Banchoff, Thomas. Religious Pluralism, Globalization and World Politics. Oxford University Press, 2008 , p. 284.
} 


\section{International Journal of Social Science and Economic Research}

ISSN: $2455-8834$

Volume: 05, Issue: 06 "June 2020"

Kamasutra is another ancient Indian Sanskrit text on sexuality, eroticism and emotional fulfilment in life. ${ }^{9}$ The kamasutra attributed to Vatsyayana ${ }^{10}$, is neither exclusively nor predominantly a sex manual on sex position" but written as a guide to the "art-of-living" well, the nature of love, finding a life partner, maintaining one's love life, and other aspects pertaining to pleasure oriented faculties of human life. ${ }^{12}$ The text contains verses describing homosexual relations between two men and between two women. For example, the fifth and eighth chapter of Book 2 of the text sheds light on lesbian relations.

According to Wendy Doniger, the Kamasutra discusses same-sex relationships through the notion of tritiya-prakriti, literally, 'third-sex' or 'third-nature'. It mentions two sorts of 'thirdnature', one where man behaves like a woman and vice versa. The term 'savirini' is mentioned and described in the text as a woman who live a conjugal life with another woman or by herself fending for herself, not interested in a husband. Alan Danielou, in his work "The Complete Kamasutra: The First Unabridged Modern Translation of the Classic Indian Text" (1973) has translated the term 'savirini' as 'lesbian'. Additionally, Kamasutra mentions about bisexual relationships. ${ }^{13}$ For example, Kamini (bisexual women) are described as those who enjoy making love with both men and women.

\section{Bahuchara Mata- Patroness of Hijra Community}

Bahuchara Mata is a Hindu Goddess (an avatar of Shakti Goddess). She is considered patroness of hijra community. ${ }^{14}$ Her primary temple is located in Beharji town in Mehsana District of Gujarat. It is believed that once when she was travelling in a caravan then a marauder named Bapiya tried to molest her. She announced 'tragu' (a form of self-immolation), and cut off her breasts, thus shedding her femininity. Thereafter, Bapiya was cursed with impotence. To attain atonement Bapiya worshipped Bahuchara Mata by dressing and behaving as a woman thus ultimately shedding his masculinity.

\section{Ardhanarishvara- Dual Male and Female Nature}

\footnotetext{
${ }^{9}$ Coltrane, Scott. Gender and Families. Rowman and Littlefield, 1998, p.36.

10 Wikipedia Contributors. "Kamasutra." Wikipedia, Wikimedia Foundat ion, 26 Jun 2019 , en.wikipedia.org/wiki/Kama_Sutra.

${ }^{11}$ Sinha, Indra. "Kamasutra." Footnotes, 2014, www.indrasinha.com/books-2/kama-sutra/.

${ }^{12}$ Carroll, Janell. Sexuality Now: Embracing Diversity. Cengage learning, 2015, p. 37.

${ }^{13}$ Doniger, Wendy. Redeeming the Kamasutra. Oxford University Press, 2016, pp. 120-122.

14 Dharmadhikari, Aditi. The Hindu Goddess Worshipped by India's Transgender Community. 7 May 2015. Homegrown, $\quad$ homegrown.co.in/article/23679/bahuchara-matas-story-a-hindu-goddess-worshipped-by-indiastransgender-community.
} 


\section{International Journal of Social Science and Economic Research}

The Hindu God Shiva is often represented as Ardhanarishvara, with a dual male and female nature. ${ }^{15}$ This is depicted in a sculpture at the Elephanta Caves near Mumbai. The Ardhanarishvara is a composite androgynous form of the Hindu deities Shiva and Parvati. It depicts the synthesis of masculine and feminine energies of the Universe. The earliest Ardhanarishvara images are dated to the Kushan period, starting from the first century C.E.

As reported by the Huffington post in 2015, for the Durga Puja Festival that took place in the month of October (2015), the most innovative idol was designed depicting the 'Ardhanarishvara' by Udyami-Yuba-Brinda Durga Puja (a local club in North Kolkata) in association with Pratyay Gender Trust (a local transgender association). The idol was prepared by China Pal (the only woman artisan belonging to Kumortuli- the idol makers' locality in Kolkata). This happened for the first time in 300 year history of Durga Puja in Kolkata. China Pal asserts, "This shows how Shakti, the female principle of God, is inseparable from Shiva, the male principle of God." Anindya Hajra, associated with the same puja comments, "Activities that are traditionally maledominated, the theme, marquee decoration, collection of subscription, puja committee formation will see the participation of transgender persons".

\section{The Legal Battle- Recognition and Acceptance}

Section 377 of the Indian Penal Code makes it illegal to engage in any 'unnatural' sexual act defined as sex other than heterosexual intercourse. The legal battle of the Transgender/LGBTQ community revolves round this section. Aids Bhedbhav Virodhi Aandolan (ABVA) was the first HIV/AIDS activist movement in India, founded in 1988 in New Delhi. ${ }^{16}$ In 1994 for the first time a petition, challenging the constitutionality of Section 377, was filed by ABVA.

Naz Foundation (an NGO committed to HIV/AIDS intervention and prevention) filed a PIL in the Delhi High Court in 2001 challenging the constitutional validity of section 377. However the Delhi High Court dismissed the original writ of the petition in 2004 for lack of cause of action. Later in 2009, in the Naz Foundation vs. Government of NCT of Delhi case, verdict resulted in decriminalization of homosexual acts involving consenting adults throughout India. In the year 2013, Section 377 was again reinstated after the verdict given in the Suresh Kumar Koushal vs. Naz Foundation case.

In 2018, in the Navtej Singh Johar vs. Union of India case, the verdict decriminalized homosexuality once again. The court was very much clear in its stand that criminalization of

\footnotetext{
${ }^{15}$ Pande, Alka. Ardhanarishvara: The Androgyne. Rupa Press, 2005.

${ }^{16}$ Fernandez, Bina. Humjinsi: A Resource Book on Lesbian, Gay, and Bisexual Rights in India. India Centre for Human Rights and Law, 1999, p.35.
} 


\section{International Journal of Social Science and Economic Research}

ISSN: $2455-8834$

Volume: 05, Issue: 06 "June 2020"

sexual acts between consenting adults violated the right to equality guaranteed by the Indian Constitution. The former C.J.I. Dipak Mishra asserts, "Section 377 is irrational, arbitrary and incomprehensible as it fetters the right to equality for LGBT community. LGBT community possess same equality as other citizens".

In a recent judgement given in the case of Arun Kumar \& Seerja vs. Inspector General of Registration and Others by the Madurai Bench of the Madras High Court on $22^{\text {nd }}$ April 2019, Justice Swaminathan draws heavily on the stories from Ramayana and Mahabharata, as discussed earlier in the paper and clearly distinguishes between sex and gender. Sex is biological and it is determined at the time of birth based on their genitalia. However, there is one category that fits into neither male nor female. These children are, by birth, inter-sex. As such the two 'sexes' of male and female do not apply to them. Herein comes the whole concept of gender. Precisely, a person has the right to identify as a particular gender irrespective of his/her sex. Justice Swaminathan asserts the fact that transgender persons have the right to self-determine their gender. The court, with reference to article 14, 19 and 21 of the Indian Constitution, said that the state shall not deny 'any person' equality before law or equal protection within the Indian Territory. "They (transgender) fall within the expression 'person' and hence are entitled to legal protection of laws in all spheres of state activity as enjoyed by any other citizen of this country"17

\section{The Transgender Persons (Protection of Rights) Bill, 2016}

The bill was introduced in August (2016) in the Lok Sabha. The bill lays down the definition of transgender persons. It also includes terms like 'trans-men', 'trans-women', 'persons with intersex variations' and 'gender queers' in its definition of transgender persons. There are provisions related to prohibition of discrimination against a transgender person in areas such as education, employment and healthcare and also direct the state/central government(s) to provide welfare scheme in these areas. Offences like compelling a transgender person to beg, denial of access to a public place, physical and sexual abuse, etc. would lead to two years of imprisonment and a fine. The bill also states that a person recognized as 'transgender' would have the right to 'self-perceived' gender identity. The bill also has provision for setting up a National Council for Transgender Persons to advise the governments on policies and legislations related to transgender persons. The bill also provides for issuance of certification of identity for a transgender person.

${ }_{17}$ Mukherjee, Jashodhara. "How Mahabharata's Shikhandi and Krishna Helped Madras HC Uphold Transwoman Also a Bride." News18, Buzz media, 24 Apr. 2016, www.news18.com/news/buzz/mahabharatas-shikhandi-andkrishna-helped-madras-hc-uphold-transwoman-also-a-bride-2114427.html. 
International Journal of Social Science and Economic Research

ISSN: 2455-8834

Volume: 05, Issue: 06 "June 2020"

The bill also suffers from certain defects. The meaning and implication of the term 'selfperceived gender identity' is not clear. The criteria specified in the definition of 'transgender persons' are not clear and there are certain terms in the definition which have not been defined. These minor defects need to be addressed before the bill becomes an act. Recently, the bill lapsed with the dissolution of the $16^{\text {th }}$ Lok Sabha and the government is willing to bring the bill before the Parliament again. If the bill becomes an act then this can prove to be a major step in bringing the transgender/LGBT persons in the mainstream of the society.

\section{CONCLUSION}

The fact cannot be denied that the concept of transgender is not new to this world. It has been in existence since time immemorial. The Indian government's dream of "SAB KA SAATH, SAB KA VIKAAS, SAB KA VISHWAS" won't be fulfilled until all of us, be it men, women, transgender/others, are a part of it. "Social morality cannot violate the rights of even one single individual", said CJI Dipak Mishra and Justice Khanwilkar. Justice Indu Malhotra also asserted that the society owes an apology to the LGBTQ community. The society should accept that people belonging to transgender community are human beings and they don't deserve any kind of inhumane treatment. India along with other nations needs to address the violations of human rights of transgender/LGBTQ people in order to raise their standard of living and bring them into the mainstream of the society. Thus, it can be concluded that if the ancient world could envision a society where transgender were given equal status then it shouldn't be difficult for the so called literati of today to appreciate the same.

\section{REFERENCES}

Cornelia, Sorabji. Shikhandi: The Maiden Night and Other Stories. Blackie and Son, 1916.

Doniger, Wendy. Redeeming the Kamasutra. Oxford University Press. 2016.

Fernandez, Bina. Humjinsi: A Resource Book on Lesbian, Gay, and Bisexual Rights in India.

India Centre for Human Rights and Law. 1999.

Pande, Alka. Ardhanarishvara: The Androgyne. Rupa Press. 2005.

Pattnaik, Devdutt. Shikhandi: And Other 'Queer' Tales They Don't Tell You. Zubaan and Penguin India. 2014.

Wilhelm, Amara Das. Tritya Prakriti: People of the Third-Sex. Xlibris. 2008. 